\title{
Epigenetic Emergence: Reading for Growth in Jane Eyre
}

Ever since Gayatri Spivak famously accused Jane Eyre of advancing feminist individualism via 'the axiomatics of imperialism', it has been difficult to read Brontë's story of female maturation and self-determination without suspicion. ${ }^{1}$ In Spivak’s account, Rochester's mad wife, figured as the barely human native female, has only a weak entitlement under the letter of the law_ - one that is easily overshadowed by theEnglishwoman's greater spiritual claim: as a rational human subject, Jane is implicitly an end in herself; as a soul-bearer, she cannot be mastered by the man who has power over her as animalistic, un-souled Bertha can be. In this way, Spivak links female autonomy and soul-making, or the forging of a rational self, to the terrorism of Kant’s categorical imperative. Even taking into consideration Bertha’s racial ambiguity, as Carolyn Vellenga Berman has argued, Brontë’s raced depiction of the mad creole is at the heart of Jane's liberation from patriarchal tyranny. This is because Jane Eyre's twinned targets of reform — the management of the (especially female) insane and a post-Emancipation Jamaican society in which intemperance, and licentiousness were thought to constitute an infectious moral malady--link the development of just domestic arrangements.to imperial governance. ${ }^{2}$ All the evidence suggests that it is impossible to talk about female independence and marriage equality in the novel without suppressing the histories of slavery, colonialismand empire that lie behind them.

Yet if form is complicit in these histories, it also pushes against them. The Bildungsroman, as a story of individual development, is certainly an account of rational soulbuilding. But as a narrative of moral development within the span of a single life, it cannot be harnessed to racial anthropology; it does not conform to an account of human nature that represents type and character at the level of population, as the result of inherited disposition, or 
as a manifestation of physical and mental difference resulting from the distribution of peoples across different regions of the globe. The Bildungsroman's emphasis on ontogeny-on the unfolding of an individual from infancy to adulthood—instead points to the internal, organismic processes that guide morphological and physiological maturation. It does so even as it positions its protagonist at the intersection of multiple external forces which must be navigated in the course of development.

In this respect, the story of maturation refuses both simple 'genetic' and environmental explanations for character. Despite Rochester's assertions that Bertha's madness is in part inherited from her maternal line and in part a casualty of the degenerative climate of the tropics, a strong Romantic strain in the novel emphasizes the creative and dynamic processes that shape interactions between inner and outer worlds during growth. In this way, the novel offers an account of development that we might now call 'epigenetic'. Epigenetics is the science of how the internal conditions of the cell orchestrate gene expression; it studies the chemical interactions that determine when and whether genetic information is translated into particular traits. Drawing upon this recognition of organismic plasticity, 'epigenetic reading', I suggest, charts the novel's resistance to anthropological distinctions between fully-human and subhuman; in this reading, Jane Eyre undermines the classification of mental types that attributes difference to a combination of heritable defects and the effects of climate. While the $19^{\text {th }}$ century Bildungsroman may seem a long way even from genetic, let alone epigenetic investigations of human nature, I shall argue that epigenetic science has roots in Romantic biology that are key to Brontë’s recognition of colluding forms of oppression. Jane Eyre, I am proposing, shows us the significance of epigenetic reading for understanding how racial anthropology is wielded in the service of domestic tyranny. 


\section{Epigenetics and Gene Expression}

Over the last several decades, evolutionary biologists and philosophers of science have challenged prevailing $20^{\text {th }}$-century assumptions that genes alone carry the executive function in development. Every time we say something like 'it's genetic' or we refer to 'the gene for x', we betray a lingering misconception that genes are simply units of heredity carrying a set of pre- determined instructions. We also align ourselves with Richard Dawkins’s 1999 account of the 'long reach' of genes, which simply exploit the organisms that host them in order to ensure their own flourishing. ${ }^{3}$ Yet as Evelyn Fox Keller announced nearly two decades ago, the notion that genes alone are at the core of biological structure and function is no longer tenable. ${ }^{4}$ Indeed, as Barry Barnes and John Dupré have shown, the transition from classical genetics to genomics (or from studies focused on units of heredity to studies of the total DNA found in the cell nucleus), has shifted attention from the gene as a unit of inheritance to the molecular systems in which DNA interacts with other molecules in mutually regulatory processes. ${ }^{5}$ Genomic science is exploring these enormously complex biochemical relations within the cell to reveal new information about organic plasticity and adaptability to changing environmental circumstances. ${ }^{6}$ The architecture of the genome, we are learning, is characterized by complex systems of innovation and regulation that mediate the expression of genetic information throughout the life cycle.

Epigenetics is at the center of this investigative turn. Coined by Conrad Waddington in the 1940s, epigenetics has enjoyed a renewed attention since the late $20^{\text {th }}$ century, stimulating inquiry into extra-genetic inheritance. Narrowly defined, it is the study of how coding DNA is expressed or silenced via chemical events (such as DNA and RNA methylation and histone modification) that occur in dynamic response to changing 
environments in the cell and beyond. More broadly defined, the field encompasses study of all that intervenes between genes and 'their' phentoypes (or observable traits), ${ }^{7}$ as well as of the 'context-dependent, self-sustaining interactions between groups of cells' that make those phenotypes stable and persistent throughout an individual life. ${ }^{8}$

Epigenetics therefore encompasses developmental plasticity in combination with what Waddington described as canalization, or the relative stabilization of characteristics within a population regardless of environment or genotype. ${ }^{9}$ But it also involves the way that organisms themselves act on their environments, building niches that will in turn affect the selective pressures on them. ${ }^{10}$ As Waddington argued, the behavior of the whole organism, as it ‘appears in nature’ can mitigate the direct effects of environment by navigating it in a particular way, and may pass along such strategies to its descendants. ${ }^{11}$ Strategic changes in habit among members of a population then ripple out through the ecosystem, prompting reconfigurations between individual and environment with implications for epigenetic variation. Where these changes are advantageous, the phenotypes they impact will become targets for genetic assimilation and thus long-term changes in a given population. And so on. As Waddington put it:

Once we consider evolution in terms of the selection of phenotypes which are produced by the development of a sample of genes drawn from a large gene pool, under the influence of an environment which is both selected by the organism and then selects the organism, we find ourselves forced to conclude that biological evolution, even at the subhuman level, is a matter of interlocking series of open-ended, cybernetic, or circular processes ${ }^{12}$ 
Thus even as epigenetics complicates our understanding of the relationship between genotype and phenotype, this does not make environmental influence any more deterministic than genetic influence. Rather, epigenetics recognizes the interpretive responses of organisms to environmental conditions and positions these responses within elaborate feedback systems operating within and across multiple levels of adaptation and selection. Epigenetic marks, or the chemical signals that determine gene expression, are the product of interactions between environmental stimuli and the 'structure, conformation, and nucleotide sequence of the DNA molecule. ${ }^{13}$ In contrast to the reductionism of classical genetics, these recent approaches therefore understand living forms as emergent: they cannot be reduced to the sum of their parts. Indeed as Keller reminds us, the very notion of separable parts and combined causal entities makes no sense in the context of development and inheritance where 'entanglement...is there from the start.' ${ }^{14}$ Living beings are the manifestation of a dynamic organization of interdependent elements in a system, interacting with other systems, and occurring along the span of a life cycle (as well as across multiple life cycles). Understood in these terms, organisms are not merely the objects through and upon which evolutionary changes takes place, but architects within their own phylogenies.

The potential for an intervention by epigenetics into cultural theory and literary analysis has been a topic of recent inquiry from several directions. Catherine Malabou’s recent Before Tomorrow: Epigenesis and Rationality asks whether the interpretive dimensions that epigenetics discovers in developmental biology open a space for recovery of the transcendental—'a power of meaning opened in the heart of the biological.' ${ }^{15}$ Elsewhere, Malabout also proposes we abandon the biopolitical paradigm within which biology is 
appropriated by the symbolic, and instead think of epigenetic plasticity as the dialectical intersection of history and biology 'within biological life itself.' ${ }^{16}$ Also addressing the problematic divide between 'life' and 'culture', a recent issue of Textual Practice has explored epigenetics as a cross-disciplinary conversation among medical geneticists and literary and cultural critics with the shared goal of speaking beyond gene-centered paradigms. The cultural- and literary-critical essays in the issue explore in various ways how ‘environments [get] under the skin’, in order to challenge the artificial separation of biology and culture and overly crude distinctions between nature and nurture. ${ }^{17}$

A lingering risk in epigenetic reading, however, lies in the concept of 'the shaping power of environment', as Angelique Richardson puts it, describing how Victorian novelists invoke epigenetics avant la lettre to represent the relationship between organism and world. ${ }^{18}$ This formulation is echoed in Josie Gill's Lamarckian definition of epigenetics as the study of how 'genes can change according to environmental circumstances and that such changes can be passed on to offspring.' ${ }^{19}$ The danger of the environmentalist emphasis is that it invokes $19^{\text {th }}$ century theories of climate-driven racial difference. In its recognition of the dangerous social effects of this science, Jane Eyre can be read as epigenetic, not in the sense of a turn to Lamarck (with whom epigenetics is sometimes disparagingly linked, ${ }^{20}$ ) but in the way it evokes Romantic biology’s emphasis on ontogeny, represented most clearly in the writings of Johann Wolfgang von Goethe. Lamarck stressed the direct influence of climate on morphology: 'when the observing naturalist travels over large portions of the earth's surface and sees conspicuous changes occurring in the environment, he invariably finds that the characters of species undergo a corresponding change.' ${ }^{21}$ By contrast, Goethe stressed the force of what he calls the archetype - an integrity of form that expresses itself and that is perceived by the observer as an 
organic whole_-a pattern that emerges through development. Material in origin, this formation occurs as the product of the living individual's interactions with the environment, but not in the way of direct impression. Rather the organization of parts in the whole, continually in motion throughout the life cycle, frame the response of the entire living being to environmental stimuli, even as the creature itself is part of a wider ecology of dynamic and interconnected relationships and wholes. ${ }^{22}$ Not coincidentally, Goethe’s Wilhelm Meister's Apprenticeship (translated by Carlyle in 1824) was a pioneer of the Bildungsroman form.

\section{Epigenesis and Monogenesis}

As remote from fiction and certainly from the $19^{\text {th }}$-century Bildungsroman as $21^{\text {st }}$ century epigenetic science might seem, it has deep roots in $18^{\text {th }}$ and $19^{\text {th }}$ century science. Indeed, Waddington coined the word itself out of the older concept of epigenesis. Introduced by Aristotle in On the Generation of Animals, and recovered by William Harvey in the $17^{\text {th }}$ century, epigenesis describes the process of organic growth in terms of the agency of organic matter itself; the various parts of the organism do not exist in miniature in the seed--as in 'preformation'--nor are they produced by the pressure of external forces. Instead organs and traits self-organize through the very movement of development or through Nature itself: 'in all the productions of Nature or of art, what exists potentially is only brought into being by what exists actually.' ${ }^{23}$ In the well-known debate about embryology between Casper Friedrich Wolff and Albrecht von Haller in the $18^{\text {th }}$ century, epigenesis became associated with vitalism, in contrast to the creationist emphasis of the preformationists. But in so doing it stressed a form of organic generation wherein living things grow and maintain themselves. ${ }^{24}$

Although Romantic Naturphilosophie at times did not align unequivocally with 
epigenesis, Romantic science generally understood growth epigenetically, attributing it at once to the original procreative agency of both parents and to the self-procreative, formative drive in nature. The latter is what Johann Friedrich Blumenbach called Bildungstrieb—a force that differentiates and organizes living matter into diverse forms, preserves the continuity of those forms, and endeavors to restore them when they are damaged. ${ }^{25}$ Bildungstrieb is not directed by the hand of God, but by Nature in which God resides. It is 'the emergence of form out of formlessness', or that which is produced by its own activity. ${ }^{26}$ Helmut Muller-Sievers has described this self-generation as a trope uniting scientific, literary, and philosophical discourse at the turn of the $19^{\text {th }}$ century—one that understood organicism as a 'chain of causes and effects...bent back into its own origin...[and containing] all the reasons or its own form and existence. $^{27}$

The Romantic concept of the dynamic archetype claimed all organic forms adhere to a single pattern from which they progressively diversify into new forms, even as this fundamental pattern exercises constraints on the pace and reach of change. In this way, Goethe's account of metamorphosis rejects at once an external teleology (one that assumes God's perfect matching of living things to their physical niches) and any understanding of environment as directly shaping the forms and habits of the creatures that inhabit it. Instead, he proposes that the living thing's interactions with its environment emerge from its organization, an inner ecology that interacts with the larger ones of which it is part, but not as mere reflex. Because unchecked plasticity would lead to chaos and formlessness, it is balanced by a 'drive for specific character, [and the] stubborn persistence of things which have finally attained reality. ${ }^{, 28}$ What Goethe calls Steigerung (heightening), or the drive of the organism to assert itself over necessity —in a sense to transcend the very stuff it is made of —is paradoxically 
deeply material and it stabilizes organic form by resisting the constant pressure of circumstance.

This has profound social and ecological implications. In his botanical writings, Goethe observed that man, viewing himself as nature's superior creation and planted on earth to dominate it, is 'accustomed to value things to the extent that they are useful to him.' ${ }^{29}$ Recognizing that life is shaped through the dynamic interplay of inner drive and outward necessity, 'from within toward without and from without toward within', 30 forces us to 'give up the habit of considering conditions and relationships as ends and purposes. 31 Steigerung disdains the algorithmic analysis of life that reduces inner drives to a set of heritable traits shaped ultimately by external forces; and in so doing, it rejects the appropriation or domination of other living beings as contrary to nature.

Such understanding therefore runs counter to the accounts of human development that underpinned imperial administrations and their archives. Environmental monogenesis—or the argument for descent from an original pair-emphasized the heritable influence of location on animals voluntarily or involuntarily transplanted from one region of the world to another. In $A n$ Essay on the Causes of the Variety of Complexion and Figure in the Human Species (1787), Samuel Stanhope Smith explained the difference of savage from civilized human types as the degenerative effect of movement into wild and uncultivated territories where they 'forget the arts of civilized life. ${ }^{32}$ In his Researches into the Physical History of Man (1813), James Prichard ( a mental physician who also published on moral insanity) agreed that certain human characteristics unique to particular races, including moral traits, are determined by cultural or climatic circumstance, and that these characteristics are generally heritable. ${ }^{33}$ Europeans (particularly women) transplanted into hot countries or descended from those who underwent 
migration, he proposed, become debilitated and susceptible to disease. ${ }^{34}$ William Lawrence (1823) and Thomas Hodgkin (1842) both similarly proposed that differences in human type are the effect of inherited changes brought about through exposure to new climates. ${ }^{35}$

Such texts entwine the study of mental malady with the fear of degenerative contagion to which settler colonists were seen to be vulnerable. In his 1772 History of Jamaica, Edward Long described both the effect of climate on White Creoles of English descent and also the corrupting effects of prolonged contact with the slave population, particularly for women. It was this very danger that necessitated careful documentation of the 'settlements, inhabitants, manners, climate, products, commerce, law and government' of plantation society, so as 'to recommend some general rules and cautions for preserving the health of those who come hither from northern climates.' 36 'Exiled beyond the reach of fatherly protection,' ${ }^{37}$ Long lamented, white Jamaicans, especially girls and women, were vulnerable to the cultural influences of their domestic African slaves, who are 'idle', 'drink to excess', and have 'no moral sensations'. ${ }^{38}$ These 'passions of the negroes’ were invoked in defense of Governor Eyre’s violent suppression of rebellion nearly 100 years later in $1865 .^{39}$

Jane Eyre challenges this climate-based account of culture and character, race, and mental and moral health through what I am calling its epigenetic depiction of the developing protagonist. Brontë's depiction of individual growth in many ways draws upon Romantic vitalism, where the drive of the organism to assert itself over necessity suggests a power from within that transcends the purely material push and pull of environment. Yet the novel also struggles to ground such drive in richly physical needs_-for food, for warmth, for sex, and for loving care. In tracing the organic maturation of a mind that in early childhood reacts to adversity with defiant rage and nervous hysteria, yet that by adulthood is powerfullyself- 
disciplining, Jane Eyre shows a debt to Goethe through the developmental arc of the Bildungsroman. It also points to his theory that steigerung stabilizes organic form in the face of continually fluctuating circumstance. In his literary criticism, Goethe stressed 'the underlying connection between desire and the moral obligation in individuals' that at once constrains through obligation and 'destinat[ion] for a specific function' and at the same time releases the desire that 'has no restraint'—a 'freedom” that exists in tension with "necessity' ${ }^{40}$ Brontë's depiction of the emerging 'soul', in particular, captures this interplay between desire and necessity and grounds it in the body. It is through the depiction of this growing body, then, that she links environmentalist monogenesis to domestic abuse.

\section{Reading for Growth in $\underline{\text { Jane Eyre }}$}

On the face of it, Jane Eyre seems unable to decide between 'genetic' and environmental explanations for character development. Rochester's mad wife Bertha is descended from generations of mad women, yet her brother's sallow skin and too relaxed features are directly attributed to his living in a hot climate. Rochester describes Jane as 'the antipodes of the Creole', suggesting that mental dispositions are determined by geography. ${ }^{41}$ Earlier, he complains of his French ward that 'coquetry runs in her blood... and seasons the marrow of her bones' (158); yet he has brought her from Paris to Yorkshire so that she may grow up 'in the wholesome soil of an English country garden’ (164). The reason for hope that Adèle will not become like her mother, or worse succumb, as Bertha does, to 'giant [sexual] propensities' that turn her into a 'wild beast' (348) is that she is lucky enough to have Jane as her governess. Jane herself was lucky in her teacher at Lowood Hall, Miss Temple, from whom she 'imbibe[d]...something of her nature and much of her habits' (98). The nutritious soil 
provided by a kind and loving substitute mother and a good education can fertilize the very nervous core of the body; and it may affect subsequent generations for the better as 'poor soil' has affected Bertha's family for the worse. Environmental influence and heredity therefore apparently combine to determine character in a way that directly endorses $19^{\text {th }}$-century theories of race and degeneration.

After all, Bertha is not only transported, imprisoned, and physically restrained by her captor; she is also powerfully raced. As the product of a diseased line whose mental incapacity is tied to the torrid climate it has inhabited for so many generations, she becomes a subject, not just of her tyrant husband, but of the technologies of imperial management. A type whose moral and mental fiber is slackened by excessive heat may be corrected and improved by transplantation; where degeneration is apparently so advanced that even a change of situation cannot check it, it must be restrained, silenced, and subdued. Jane describes Bertha’s horrifying apparition as having 'a discoloured face... a savage face' with 'fearful blackened inflation of the lineaments' (317). That her violence and savagery are a form of 'discolouration' confirms that both can be attributed to the toxicity of the tropical environment in which too many generations of her family have lived.

Yet at the same time, the narrative recognizes how imperial ideology and evolutionary anthropology have conspired to make female passion an object of discursive management both in the metropolitan domestic sphere and in the colonial periphery. And it offers an alternative representation of female bodies in dynamic relation with their worlds. Jane is often sustained by an apparently innate 'inward power' (341): as a young child refusing to submit to her bullying adoptive brother; later, when she summons the mental resilience to leave Rochester when the alternative is to become his mistress; then later again when her cousin, St John Rivers, presses 
her to become his missionary wife (and devote her life to the cause of 'regenerating' (435) the lower races), and she is pulled away by her desire for the former man-a drive powerful enough to conjure up his voice across miles of moorland. Although in childhood she is paired with Bertha as an 'animal' (15) whose wild behavior invites extreme forms of discipline, Jane is able to avoid the other's fate by building her physical passions and needs into something she calls soul, but which could also be described as an assertion of character that emerges from the dynamic relations among circumstance and embodied thought. Her epiphanic longing for 'a new servitude!'(100), for example, is unlike any 'hollow and fleeting' dream of Liberty or anything else unattainably sweet; instead it is something 'matter of fact', drawing upon her past and present circumstances. As such it 'order[s her] brain to find a response' so that she feels 'the pulses throb in [her] head' (100) and eventually hears a voice from within telling her how to act.

This ‘something', best described as ‘soul' or 'spirit' remains fully material, not because it can be reduced to a fluttering of cerebral events, but because the inner voice defining the objects of will and desire emerges out of the sequence of life events (from abused orphan to deprived schoolgirl and devoted friend, to adoring mentee) but not as the mere sum of them; it is not a mechanical, reflex response to external circumstances, but nor is it the product of a prescripted nervous physiology (something Jane monitors very carefully, always fearful that she may be motivated by nervous hypochondria). Rather it is the forming of a life story, a patterning of events into a story of growth, as Jane recognizes emancipatory possibilities within the very constraints of her circumstances. This narrative drive then directs her neural processing, and reorients her in the landscapes and situations she moves through with deliberation, and which she continually transforms through her presence. Such drive is manifest at times as the expression of passion-'a vehemence of emotion... asserting a right to 
predominate: to overcome, to live, rise, and reign at last' (283)_; at other times it emerges in the discovery of identity through hitherto unrevealed connections-a discovery that is registered in the body even as it realizes the knitted coherence of events and characters in relation to a single life that makes the Bildungsroman cohere:

I stopped: I could not trust myself to entertain, much less to express, the thought that rushed upon me -that embodied itself — that, in a second, stood out a strong, solid probability. Circumstances knit themselves, fitted themselves, shot into order: the chain that had been lying hitherto a formless lump of links, was drawn out straight-every ring was perfect, the connection complete. (429)

Brontē therefore takes up what Keats, in the 'Vale of Soul Making' describes as the transformation of identity through a 'world of circumstances', but she locates it firmly in the body. ${ }^{42}$ While Jane admires her consumptive friend Helen Burns's belief in the equality of souls that will be realized when we cast off our corruptible flesh and the capacity it gives her to bear her suffering, she cannot embrace this idea any more than she can tolerate the brutal school manager Brocklehurst's doctrine that to feed the 'vile body' (75) is to starve the immortal soul. She cries out in protest at Rochester's feigned indifference to her feelings that, just because she is a woman and his social inferior, she has no less need for bread or water or any less sexual and romantic longing than he-feelings that she describes as 'soul' and 'heart', but which she clearly links to physical needs as much as to spiritual ones (284). Finally, she is able to withstand the severity of St John's insistence that she sacrifice her worldly feelings to become his helpmeet in a passionless marriage and bend her will to his. Not only is the soul 
formed as the body absorbs experience, but it expresses itself through fundamental urges of the body—-through the need for food, warmth, love, and through sexual desire. Moreover, as Jane asserts her identity as equal to that of the men who pursue her, the novel itself becomes part of a landscape in which the physicalized passions and sympathies of a reader who is repeatedly apostrophized by the narrating Jane can also coalesce into a soul-bearing personality. This coming forth of ensouled beings at the intersection of body and world pushes against the abstraction of female feeling into so many heritable units of character and so much direct shaping of character by climate.

This is important because in Rochester's account of her, Bertha's sexuality is what marks her as degenerate and animal—as a creature lacking soul. Jane's outbursts, on the other hand, protest that women's souls are crushed by tyranny. Although at times she participates in the racializing and dehumanizing of Bertha, the two women are clearly linked: Jane too was called a 'bad animal' (15) when she struggled against her captivity in childhood, and her obviously justified attack on her cousin in the opening pages of the novel can't quite be forgotten when Bertha lunges at Rochester. In her desperate struggle against her Gateshead captors, Jane describes herself as a 'rebel slave' (19). This cannot be a matter of one woman maturing to abjure the violent impulses of childhood and learn her place when the other does not, for Jane's young adult life is also shaped by her struggles against tyranny—refusing to let Rochester condemn her to a life of sexual slavery on the one hand and rejecting a marriage that would crush her identity and deny her sexuality on the other. The embodied female soul, in other words, is constantly under threat of evisceration. Even though it is constituted by and through biological functions - the needs of stomach, body temperature, sexual organs and the 'flesh on bone' (16) that shrinks in fear at an aggressor-each of which reacts to, absorbs, and transforms experience 
throughout the life cycle, its assailants seek to tear that soul away from the body, which may then be safely despised, possessed, dominated, and untroublingly self-immolated.

In refusing to mobilize the developmental coordinates of heredity and environment to map racial, class, and gender differences, then, the novel turns to the epigenetic circuitry that puts body, environment, and character into dynamic interrelation in a way that generates a distinctly material soul. Soul-making is Bildung: development, becoming, change, reformation. Souls are built in the 'exertion of [a]free independent will' (216) that is nonetheless of the body. Bertha is denied soul not because she is too highly sexualized—and therefore 'mad' — to be capable of it (as much as Rochester tries to insist), but because her body is already the object of an imperial discourse that has inserted it into a geography and a genealogy of sexual behavior. Jane, of course, has the advantage of having been born in England. But that is not everything, since it has not saved her frivolous cousin Georgiana from 'idiocy’ (265). The source of Jane's resilience- - her willed resistance against the many figures in her life who seek to define her nature, and the way she can draw upon 'some strange expedient to achieve escape from insupportable oppression'(22) — is neither her parentage nor her circumstances; rather it is the yearning of growth itself — to form and to be formed archetypally (in Goethe’s sense) by experience and bodily passions: 'quickened with all of incident, life, fire, feeling, that I desired and had not [yet] in my actual existence' (92). Hence her crying out against Rochester: 'you think that because I am poor, weak, and plain and little, I am soulless and heartless.' Soul-making is a refusal to let circumstance and inherited physical characteristics become the coordinates of a calculable nature that can then be reliably governed. In his moment of greatest despair, Rochester recognizes that while he has the power to seize her body, he cannot take possession of her soul, and while he interprets this as something non-material, 
insisting that she is part fairy, she responds that she is as human as he is. It is not just Rochester's physical and social power over her that her soul resists, but also the broader social prediction that based on poor environment and dubious parentage, she will necessarily succumb to such power.

In Spivak’s account of the novel, missionary work creates an ideological bridge between the gothic 'madwoman in the attic' narrative and the vocational alternative to the marriage plot represented by the St John Rivers story: the glorious deeds of the colonizer will transform ignorant animals into rational human subjects. In this respect, her essay also looked ahead a few years to 'Can the Subaltern Speak?’ Here, for the colonial archive, sati becomes the site of 'benevolent' imperial management. Bertha's self-immolation is just one more sign of her subhumanity and incapacity for soul. Yet is it possible to see the novel as rather more conscious of the way that sacrifice underpins imperial discourse than Spivak suggested, and to understand material soul-building as offering some resistance to colonial brutality. Jane’s protest against the gender and class privileges that would silence her, exerted through the needs of the growing body, is also a refusal to accept Rochester's suppression of female passion through his appeals to racial science. The challenge is made on Bertha's behalf as well as her own.

From Gilbert and Gubar’s The Madwoman in the Attic to Spivak’s essay and beyond, critics have rightly focused on the silencing and dehumanizing of Bertha in contrast with Jane’s assertions of selfhood. ${ }^{43}$ I've tried to suggest that the novel itself not only draws attention to their common expressions of resistance, but that it identifies and challenges the science that defines their differences of character. The novel's 'extra-genetic' representations of developing soul and mind are inherently critical of the environmentalist monogenesis that lies at the heart 
of everything that Rochester believes about Bertha. By resisting the coordinates of racial biology —heredity on the one hand; environment on the other—-the Bildungsroman can therefore be read as epigenetic. I mean this both in the sense of epigenesis—-the self-creating powers of a living thing — and in the modern sense of epigenetics, where complex systems of feedback between world and creature mediate the expression of genetic information. Form, Bildung, is the unfolding of a life in dynamic relation with its environments, enabling creativity and innovation within the constraints of the developmental channels which sustain that life. Reading Jane Eyre epigenetically shows us that to speak against inequality means to remember that the body is always more than it inherits and something other than the mere sum of its circumstances. 
${ }^{1}$ Gayatri Chakravorty Spivak, ‘Three Women’s Texts and a Critique of Imperialism’, Critical Inquiry 12.1 (Autumn 1985), 243-61 (247).

${ }^{2}$ Carolyn Vellenga Berman, Creole Crossings: Domestic Fiction and the Reform of Colonial Slavery (Ithaca: Cornell University Press, 2006), 122-143.

${ }^{3}$ Richard Dawkins, The Extended Phenotype: The Long Reach of the Gene (Oxford: Oxford University Press, 1999.)

${ }^{4}$ Evelyn Fox Keller, The Century of the Gene (Cambridge, MA: Harvard University Press, 2000), 9. Qtd in Mandy Bloomfield and Clare Hanson, 'Beyond the Gene: Epigenetic Science in $21^{\text {st }}$ Century Culture', Textual Practice 29.3 (2015), 405-415 (405).

${ }^{5}$ Barry Barnes and John Dupré, Genomes and What to Make of Them (Chicago: University of Chicago Press, 2008), 7-8. The regulatory aspects of these systems include generating proteins with 'housekeeping' functions that maintain cell health and the functioning of organisms (50).

${ }^{6}$ Gregory A. Wray, 'Integrating Genomics into Evolutionary Theory’, in Evolution: The Extended Synthesis, edited by Massimp Pigliucci and Gerd B. Müller (Cambridge, MA: MIT Press, 2010), 97-116 (110); Pigliucci and Müller, ‘Introduction’, Evolution, 14.

${ }^{7}$ Eva Jablonka and Ehud Lamm, 'The Epigenotype: A Dynamic Network View of Development', International Journal of Epidemiology 41.1 (Feb. 2012), 16-20 (16).

${ }^{8}$ Eva Jablonka and Gal Raz, 'Transgenerational Epigenetic Inheritance: Prevalence, Mechanisms, and Implications for the Study of Heredity and Evolution', The Quarterly Review of Biology 84:2 (June 2009), 131-74 (132).

${ }^{9}$ Conrad H. Waddington, 'Canalization of Development and Genetic Assimilation of Acquired Characteristics,' Nature 183 (13 June 1959), 1654-55; Waddington, The Strategy of the Genes: A Discussion of Some Aspects of Theoretical Biology (Oxford: Routledge, 2014 [1957]), 19. 
${ }^{10}$ F. John Odling-Smee, Kevin N. Lanland and Marcus W. Feldman, Niche Construction: The Neglected Process in Evolution (Princeton, N.J.: Princeton University Press, 2003); Eytan Avital and Eva Jablonka, Animal Traditions: Behavioral Inheritance in Evolution (Cambridge:

Cambridge University Press, 2000); Eva Jablonka and Ehud Lamm, 'The Epigenotype: A Dynamic Network View of Development', International Journal of Epidemiology 41.1 (Feb. 2012), 16-20.

${ }^{11}$ C.H. Waddington, 'Evolution in the Subhuman World', in Erich Jantsch and C.H. Waddington (eds.), Evolution and Consciousness: Human Systems in Transition (Massachusetts: AddisonWesley, 1976), 11-15 (12).

12 'Evolution in the Subhuman World', 15.

${ }^{13}$ Keller, Century of the Gene, 7.

${ }^{14}$ Century of the Gene, 6.

${ }^{15}$ Catherine Malabou, Before Tomorrow: Epigenesis and Rationality, trans. Carolyn Shread (Cambridge: Polity Press, 2016), 89.

16 ‘The King’s Two (Biopolitical) Bodies’, Representations 127.1 (Summer 2014): 98-106 (105).

${ }^{17}$ Mandy Bloomfield and Clare Hanson (eds.) Beyond the Gene: Epigenetic Science in $21^{\text {st }}$ Century Culture, special issue of Textual Practice 39.3 (2015). See especially, Bloomfield and Hanson, ‘Beyond the Gene’, 405-13; Jim Osborne, ‘Getting Under Performance’s Skin: Epigenetics and Gender Perfomativity’, 499-516; Hanson, ‘Epigenetics, Plasticity and Identity in Jackie Kay’s Red Dust Road’, 433-452; Josie Gill, ‘’Under Extreme Environmental Pressure, Characteristics were Acquired”: Epigenetics, Race, and Salman Rushdie’s The Satanic Verses', 479-498; Bloomfield et al, ‘Beyond the Gene Roundtable Discussion’, 415-32.

18 'Beyond the Gene Roundtable Discussion’, 416. 
${ }^{19}$ Gill, ‘Under Extreme Environmental Pressures’, 479.

${ }^{20}$ On competing definitions of Lamarckism now and at the end of the $19^{\text {th }}$ century, see Fern Elsdon-Baker, 'Contested Inheritance: Debates on the Role of “Inheritance of Acquired Characteristics” in Late Nineteenth-Century Darwinian and Weismannian Thought', Textual Practice 39.3 (2015): 547-571.

${ }^{21}$ J. B. Lamarck, Zoological Philosophy: An Exposition with Regard to the Natural History of Animals, trans. Hugh Elliot (London: MacMillan \& Co., 1914), 112.

${ }^{22}$ Craig Holdrege, 'Goethe and the Evolution of Science’, In Context 31(Spring 2014), 10-23;

Dorothea Von Mücke, ‘Goethe’s Metamorphosis: Changing Forms in Nature, the Life Sciences, and Authorship’, Representations 95 (Summer 2006), 27-53.

${ }^{23}$ Aristotle, Works of Aristotle Vol. V: On the Generation of Animals, trans. J.A. Smith and W.D. Ross, 734.

${ }^{24}$ The absolute distinction between preformation and epigenesis in this literature is a matter of dispute, and may be understood in terms of competing objects of investigation and methodologies. See Karen Detlesfen, 'Explanation and Demonstration in the Haller-Wolff Debate', in The Problem of Animal Generation in Early Modern Philosophy, ed. Justin E.H. Smith (Cambridge: Cambridge University Press, 2006), 235-261 (241).

${ }^{25}$ Johann Friedrich Blumenbach, Über den Bildungstreib und das Zeugungsgeschäfte, $1^{\text {st }}$ ed. (Göttingen: Johann Christian Dieterich, 1781), 12-13. Quoted in Robert J. Richards, Thee Romantic Conception of Life: Science and Philosophy in the Age of Goethe (Chicago: University of Chicago Press, 2002), 218. Blumenbach applied his work in comparative anatomy to the classification of human races, identified racial distinctions as degenerative, and employed anthropometry and craniometry to do so, anticipating $19^{\text {th- }}$ and $20^{\text {th }}$ - technologies of scientific 
racism. However, he was careful to emphasize that the 'varieties of mankind' created by climate, nutritional, and cultural differences, ran together and that it is not possible to 'mark out the limits between them'. Every distinctive bodily character is one classification of human being could be found in many others. Moreover, he emphasized that the classifications did not carry over into mental attributes. Johann Friedrich Blumenbach, The Anthropological Treatises, trans. Thomas Benyshe (London: Longman, Green, \& Roberts, 1865), 98, 305-310.

${ }^{26}$ Jocelyn Holland, The Procreative Poetics of Goethe, Novalis, and Ritter (New York: Routlege, 2009), 6.

${ }^{27}$ Helmut Müller-Sievers, Self-Generation: Biology, Philosophy and Literature around 1800 (Stanford: Stanford University Press, 1997), 4. Quoted in Holland, Procreative Poetics, 9. Holland challenges the strong dichotomization of preformation and epigenesis in MüllerSievers's account.

${ }^{28}$ Johann Wolfgang von Goethe, Sämtliche Werke, ed. Hendrik Birus et al., 40 vols.(Frankfurt: Deutscher Klassiker Verlag, 1985), 12: 43. Quoted in Astride Tantillo, The Will to Create: Goethe’s Philosophy of Nature (Pittsburg: University of Pittsburg Press, 2002), 131.

${ }^{29}$ J. W. Goethe, 'An Attempt to Evolve a General Comparative Theory', in Goethe’s Botanical Writings, ed. Charles J. Engard, trans. Bertha Mueller (Honolulu: University of Hawii Press, 1952), 81-4 (82).

${ }^{30}$ Goethe, 'An Attempt', 83.

${ }^{31}$ Goethe, 'An Attempt', 84

32 . Samuel Stanhope Smith, An Essay on the Causes of the Variety of Complexion and Figure in the Human Species $2^{\text {nd }}$ edn. (New Brunswick: J. Simpson \& Co., 1810), 17.

${ }^{33}$ James Cowles Prichard, Researches into the Physical History of Man, edited by George W. 
Stocking (Chicago: University of Chicago Press, 1973), 33-5.

${ }^{34}$ Prichard, Researches, 172.

${ }^{35}$ William Lawrence, Lectures on Physiology, Zoology, and the Natural History of Man, $3^{\text {rd }}$ edn. (London: James South, 1823), 205-33; Thomas Hodgkin, 'On Inquiries into the Races of Man’, Reports of the British Association for the Advancement of Science 11 (1842), 52-5.

${ }^{36}$ Edward Long, The History of Jamaica: Reflections on its Situation, Settlements, Inhabitants, Climate, Products, Commerce, Law and Government, Vol II [1774] (Montreal: McGill-Queens University Press, 2002), 2.

${ }^{37}$ History of Jamaica, 3.

${ }^{38}$ History of Jamaica., 354.

${ }^{39}$ W.F. Finlason, The History of the Jamaica Case: Being an Account founded upon official documents of the Rebellion of the Negroes in Jamaica ( $2^{\text {nd }}$ edn.) (London: Chapman and Hall, 1869), vii.

${ }^{40}$ J.W.Goethe, 'Shakespeare Once Again,' Johann Wolfgang von Goethe: Essays on Art and Literature, ed. John Gearey, trans. Ellen and Ernest H. von Hardroff (New York: Suhrkamp Publishers, 1986), 166-174 (170).

${ }^{41}$ Charlotte Brontē, Jane Eyre, ed. Michael Mason (New York: Penguin, 2003), 349. All further references cited in the text.

42 ‘John Keats to George and Georgiana Keats’, 14 Feb. 1819, The Letters of John Keats 18141821, edited by Hyder Rollins (Cambridge, Mass.: Cambridge University Press, 1956),vol. 2 81:102.

${ }^{43}$ There are too many to list here. On the metaphorical co-option of colonial slavery to represent gender relations in Jane Eyre, see for example Susan Meyer, 'Colonialism and the Figurative 
Strategy of Jane Eyre', in Macropolitics of Nineteenth-Century Literature: Nationalism, Exoticism, Imperialism, eds. Jonathan Arac and Harriet Ritvo (Philadelphia: University of Pennsylvania Press, 1991), 159-83; Patrick Brantlinger, 'Victorians and Africans: The Genealogy of the Myth of the Dark Continent', Critical Inquiry 12 (1985), 166-203. More recent accounts of the colonial and gender politics of the novel include Berman, Creole Crossings and Eve Walsh Stoddard, Positioning Gender and Race in (Post)colonial Plantation Space: Connecting Ireland and the Caribbean (New York: Palgrave Macmillan, 2012).

\section{Acknowledgements}

All my preliminary thinking about and drafting of this essay took place in conversation with my colleague, Paul Outka. Although we ultimately took different paths in what began as a collaborative project, I owe this final result to his tremendous intellectual generosity as well as to insightful comments from him, Elizabeth Outka, Dorice Elliott, and Talia Schaffer on my reading of Jane Eyre. 